\title{
Molecular Basis of Drug Resistance and Insights for New Treatment Approaches in mCRPC
}

\author{
SILVANA GIACINTI ${ }^{1}$, GIULIA POTI ${ }^{2}$, MICHELA ROBERTO $^{2}$, SERENA MACRINI ${ }^{2}$, \\ MARIA BASSANELLI ${ }^{3}$, FRANCESCA DI PIETRO ${ }^{2}$, ANNA MARIA ASCHELTER ${ }^{4}$, \\ ANNA CERIBELLI ${ }^{3}$, ENZO MARIA RUGGERI ${ }^{1}$ and PAOLO MARCHETTI ${ }^{2}$ \\ ${ }^{1}$ Belcolle Hospital ASL Viterbo, Viterbo, Italy; \\ ${ }^{2}$ Sapienza University of Rome, Rome, Italy; \\ ${ }^{3}$ San Camillo Del Lellis Hospital ASL Rieti, Rieti, Italy; \\ ${ }^{4}$ Sant'Andrea Hospital of Rome, Rome, Italy
}

\begin{abstract}
Inhibiting androgen receptor (AR) signaling with androgen deprivation therapy (ADT) represents the mainstay of therapy for advanced and metastatic prostate cancer. However, about 20-60\% of patients receiving first-line treatment for prostate cancer will relapse, evolving in a more aggressive and lethal form of the disease, the castrationresistant prostate cancer (CRPC), despite the use of ADT Multiple approved systemic therapies able to prolong survival of patients with metastatic CRPC (mCRPC) exist, but almost invariably, patients treated with these drugs develop primary or acquired resistance. Multiple factors are involved in CRPC treatment resistance and elucidating the mechanisms of action of these factors is a key question and an active area of research. Due to such a complex scenario, treatment personalization is necessary to improve treatment effectiveness and reduce relapse rates in CRPC. In this review, current evidence about the major mechanisms of resistance to the available prostate cancer treatments were examined by introducing insights on new and future therapeutic approaches.
\end{abstract}

Inhibiting androgen receptor (AR) signaling with androgen deprivation therapy (ADT) [i.e. surgical castration, luteinizing hormone-releasing hormone (LHRH) analogues] represents the first example of a 'targeted' therapy for advanced and

This article is freely accessible online.

Correspondence to: Silvana Giacinti, MD, Department of Oncology, Belcolle Hospital ASL Viterbo, 01100 Viterbo, Italy. Tel: +39 0761339040, Fax: +39 0761339043, e-mail: silvanagiacinti@ gmail.com

Key Words: Prostate cancer, metastatic CRPC, androgen deprivation therapy, drug resistance, review. metastatic prostate cancer (PCa). About $20-60 \%$ of patients receiving a primary treatment for their $\mathrm{PCa}$ will relapse, despite use of ADT (1-3).

Tumor outgrowth during ADT represents a key transition point from hormone-sensitive disease to a more aggressive and ultimately lethal form, the castration-resistant prostate cancer (CRPC) (4). Currently, there are multiple approved systemic therapies able to prolong survival of patients with mCPRC. These include cytotoxic compounds (i.e. docetaxel and cabazitaxel), AR-targeted therapies (i.e. enzalutamide and abiraterone), and the radioisotope radium-223 (5-8). Unfortunately, most patients treated with these drugs develop primary or acquired resistance during their clinical course. Therefore, knowledge of resistance mechanisms to the available therapeutic agents for $\mathrm{mCRPC}$ is a key question and an active area of research (9)

Herein, current evidence about the major mechanisms of resistance to $\mathrm{PCa}$ treatments is reviewed and insights on new and future therapeutic approaches are introduced.

\section{Taxanes: Mechanism of Action}

Taxanes represent an important chemotherapeutic class of drugs, which have demonstrated survival benefits in MCRPC therapy.

In 2004, docetaxel became the standard treatment for chemotherapy-naive mCPRC patients, according to Phase-III clinical trials TAX327 and SWOG 99-16. These large trials compared patients treated with docetaxel $v s$. mitoxantrone and showed longer overall survival (OS) in docetaxel group $(5,6)$. Cabazitaxel, a new-generation taxane, was developed to overcome resistance to docetaxel, because of its low affinity for P-glycoprotein (P-gp), an ATP-dependent drug efflux pump. In TROPIC Phase-III trial, cabazitaxel plus prednisone therapy demonstrated a prolonged survival (up to 15.1 months) and a 
reduced risk of death (up to 30\%) in mCRPC patients progressed during or after docetaxel-based therapy (6).

Microtubules are composed of a backbone of tubulin dimers and microtubule-associated proteins. The mechanism of action of taxanes can be explained by their capacity to bind strongly to the polymers of tubulin. Taxanes site of action is $\beta$-tubulin and their antimitotic effects are exerted by reducing spindle microtubule dynamics, leading to the arrest of the cell cycle in the mitotic phase $\left(\mathrm{G}_{2} / \mathrm{M}\right)$. Taxanes have been reported to induce apoptosis, activation of several cellular signaling pathways, inhibition of intracellular trafficking, proteins nuclear translocation decrease (i.e. p53, AR) (10-14).

Despite numerous studies, the exact mechanisms of both taxane action and resistance are still unclear. The resistance is due to several contributing factors, such as: tubulin alterations, kinesins, overexpression of multi-drug-resistance (MDR), ETS fusion genes family, signaling pathways and cytokines and epithelial-mesenchymal transition (EMT), AR splice variants (15-17). Elucidating the mechanisms of taxane resistance may provide evidence for the discovery of novel biomarkers and drug development in CRPC.

\section{Tubulin Alteration}

As far as taxanes target the cytoskeleton directly, several studies have demonstrated that a mechanism of resistance is performed by a different expression of $\beta$-tubulin subunits, which could influence the response to these drugs. In 2010, Terry et al. have reported an association between high expression of $\beta$ III-tubulin and tumor aggressiveness in PCa patients receiving taxane-based chemotherapy. They also showed that $\beta$ III-tubulin silencing increased sensitivity to docetaxel. According to their findings, $\beta$ III-tubulin expression might be a predictive biomarker of tumorresistance, mainly associated with local-spreading disease, involved lymph-nodes, and increasing prostate-specific antigen (PSA) levels (15).

Overall the results of the various conducted studies highlight the difficulty in isolating the contribution of single tubulin isotypes in drug response. Ranganathan et al. tested the effects of $\beta$-tubulin overexpression on anti-microtubule drug response, in human prostate carcinoma cells. They revealed that overexpression of $\beta$ III isotype in human prostate carcinoma cells by stable transfection failed to confer anti-microtubule drug resistance to these cells. This finding emphasizes the difficulty in isolating the contribution of single tubulin isotypes in drug response studies (16).

Two further studies of the groups of Hari et al. and Hara $e t$ $a l$. have shown that other potential mechanisms of tubulinmediated resistance are the point mutations in $\alpha$ - and $\beta$ tubulin. In their preclinical experiences, $\beta$-tubulin mutations, such as T26A, A595G, and F270I, have been related to an impaired taxane-mediated polymerization. However, it is still unknown whether these mutations are simple epiphenomenon or an effective resistance mechanism, and their biological relevance, in vivo $(17,18)$.

Recently, new drugs have been tested in an attempt to overcome chemo-resistance. For example, Souchek et al. studied NanoOrl, a new formulation of the drug Orlistat (19). Taccalonolides, a new class of microtubule stabilization agents derived from plants of the genus Tacca, have been shown to overcome taxane resistance through stabilizing microtubules in a different manner compared to other microtubule stabilizers (20).

In conclusion, several new molecules have to be more investigated to identify biomarkers in CRPC.

\section{Kinesins}

Kinesins, which are involved in intracellular microtubule transport and mitosis, have been studied regarding CRPC response to therapy. Sircar et al. demonstrated that the mitotic centromere-associated kinesin (MCAK) had increased expression in docetaxel-resistant CRPC compared to chemotherapy-naïve CRPC and hormone-sensitive PCa. Moreover, MCAK knockdown experiments resulted in growth arrest of prostate cancer cells, thereby suggesting MCAK as a novel target for CRPC therapy (21). On the other hand, another kinesin, Eg5, was significantly related to major docetaxel response rate, according to Wissing's study (22).

\section{Multidrug Resistance Phenotype}

One of the most investigated features in taxane resistance mechanism in mCRPC is overexpression of ATP-binding cassette (ABC) or multidrug resistance (MDR) transporters (23). These proteins are transmembrane ATP-dependent efflux pumps, belonging to the $\mathrm{ABC}$ transporter superfamily, that have the ability to carry drugs and other xenomolecules out of the cells. Prostate tumor grade, stage, and PSA level have been directly correlated with expression of ABCB1; moreover, worse clinical outcome and toxicities have been associated with ABCB1 gene allelic variants (24).

Van Brussel et al. (25) studied the role of the MDR phenotype in several human PCa cell lines, and determined the expression of several proteins involved in this process, like Bcl-2, Bax, P-glycoprotein (Pgp), multidrug resistanceassociated protein (MRP), topoisomerase (Topo) I, II $\alpha$ and II $\beta$, glutathione-S-transferase- $\pi$ (GST- $\pi$ ). Based on their findings, Zhu et al. (26) studied the role of ABCB1 in docetaxel resistance. They found that overexpression of ABCB1 (P-glycoprotein/MDR1), ABCC4 and ABCC5 promoted taxane resistance, suggesting that blocking $\mathrm{ABCB} 1$ could represent a novel approach for resensitizing to docetaxel treatment. Furthermore, they showed (27) that 
Table I. Mechanisms of resistance to taxanes.

Tubulin alterations

Kinesins

Multidrug Resistance Phenotype

ERG and TMPRSS3-ERG Fusion Gene Growth Factors, Apoptosis Regulators and Intracellular Pathways

EMT Transition

Cytokines/Inflammation

Androgen Receptor

\author{
Hyper-expression of beta-III tubulin and mutations in alpha and beta tubulins increases taxane resistance \\ Kynesins protein family is implicated in taxanes- resistance mechanisms by interacting with microtubules \\ Overexpression of $\mathrm{ABAB} 1, \mathrm{ABCC} 4$ and $\mathrm{ABCC} 5$ promotes taxanes resistance through \\ increasing their excretion from tumoral cells \\ When fused together ETS proteins are aberrantly transcribed, decreasing taxanes sensitivity \\ Reduction of apoptosis regulators, increasing of GATA2 and IGF2 growth factors and \\ up-regulation of Notch and Hedgehog signalling pathways are linked to cancer resistance \\ In Epithelial-to-Mesenchimal transition there ia a reduced expression of micro-RNAs such as \\ miR-200C and miR-205 associated with docetaxel resistance \\ IL-6, IL-8, chemokines ligand2, TGF beta1 and MIC-1 promote Docetaxel resistance \\ Androgen Receptor splicing variants, such as ArV567 and ArV7 are implicated in taxanes sensitivity
}

bicalutamide and enzalutamide inhibited ABCB1 ATPbinding cassette transporter activity through blocking ABCB1 efflux activity by $40 \%$ and $60 \%$, respectively, and in a dose-dependent manner. Bicalutamide, therefore, has been shown to resensitize cells to docetaxel treatment independently of the $\mathrm{AR}$ status, in vitro and in vivo; the association of bicalutamide with docetaxel was reported to have an important antitumor effect in AR-positive and ARnegative mouse models.

Oprea-Lager et al. (28) demonstrated that ABCC4, which is induced by androgens, is involved in docetaxel resistance. In their preclinical study, the authors observed that the ABCC4 protein (determined by western blotting) was expressed in taxane-resistant cells lines (MLL), while no $\mathrm{ABCC} 4$ was detectable in prostate cancer cells line (PCa3) sensitive to docetaxel and cabazitaxel. Also, they revealed that ABCC4 inhibition by the MRP inhibitor MK571 almost completely reversed resistance in vitro to docetaxel of MLL cells. Thus, cabazitaxel was found to be equally effective in both MLL and ABCC4 models, while ABCC4-positive cells line was far less sensitive to docetaxel (29). Cabazitaxel has therapeutic efficacy independently of ABCC4 expression.

The main taxane mechanisms of resistance are summarized in Table I.

\section{ERG and TMPRSS2-ERG Fusion Gene}

Tomlins et al. (30) showed that gene fusion between TMPRSS2 (encoding a transmembrane serine protease constitutively expressed in prostate) and ETS family genes (ERG, FL11, ETV4 and ETV5) occur at a high frequency in PCa. When fused together, ETS proteins were aberrantly transcribed; the downstream activation of ETS target genes resulted in abnormal cellular proliferation. In another in vitro study, it was demonstrated that the TMPRSS2-ERG rearrangement might have a predictive value for response to Poly (ADP-ribose) polymerase (PARP) inhibitors in early and metastatic PCa (31).
ERG affects several parameters of microtubule dynamics and inhibits effective drug-target engagement of taxanes with tubulin (32). Galletti et al. studied the effects of ERG overexpression using in vitro and in vivo models of CRPC, and they revealed its capacity to decrease sensitivity to taxanes. They analysed a cohort of 34 men with mCRPC and showed that the over-expression of ERG doubles the probability of docetaxel resistance when compared with ERGnegative cancer. Specifically, they observed a PSA response to docetaxel therapy in the $45 \%$ and $79 \%$ of ERG-TMPRSS2 positive and negative patients respectively ( $p=0.056$, odds ratio $=0.23(0.05-1.0995 \%$ confidence interval).

It has been proven that ERG protein acts like a regulator of gene expression inside the nucleus, but in the cytoplasm, it can also bind to soluble tubulines, with detriment of the tubulin polymer, that are the main target of taxanes antitumoral action (33). This leads to a lack of sensitiveness towards these drugs but on the other hand to sensitization to microtubule depolymerizing drugs (34).

\section{Growth Factor, Apoptosis Regulators, and Intracellular Pathways}

Several studies have demonstrated that docetaxel-resistant PCa cells show alterations of cell survival factors and apoptosis regulators such as Bcl-2, clusterin, heat shock proteins (HSPs), and activation of transcription pathways (STAT1, STAT3, NF-k1) (35). Other molecules and pathways associated with cancer chemotherapeutic resistance are p53, NF-kB, PI3K-Akt, and interleukin (IL)-6/STAT3 (36); some of these have also been related to resistance to taxanes (37-39). Vidal et al. (40) described 13 different genes that were frequently deregulated in docetaxel-resistant-PCa datasets. Among these genes, GATA2 and insulin-like growth factor 2 (IGF2) were increased in taxane-resistant cell lines and CRPC progression, and conferred aggressiveness in PCa cells. Overexpression of Notch and Hedgehog signaling pathway have also been shown to confer taxane resistance in 
PCa (41). Finally, Liu et al. (42) demonstrated the association between p53 phosphorylation and docetaxel sensitivity in PCa cells.

\section{Epithelial-to-mesenchimal Transition (EMT)}

Puhr et al. (43) demonstrated that expression of microRNA (miR)-200c and miR-205 in docetaxel-resistant cell lines (PC3-DR and DU-145-DR) which underwent EMT was significantly reduced compared to non-docetaxel resistant human prostate cell lines. Cells with the mesenchymal phenotype showed increased invasive and migratory abilities and decreased adhesive properties. Moreover, tumor relapse associated with reduced E-cadherin levels (44).

\section{Cytokines and Inflammation}

There is evidence that overexpression of inflammationassociated molecules (i.e. pro-inflammatory cytokines) can lead to docetaxel resistance. Overexpression of IL-6 inhibits apoptosis and promotes cell proliferation. Furthermore, IL-8, transforming growth factor- $\beta 1$ (TGF- $\beta 1$ ), chemokine ligand 2 (CCL2) (45) and macrophage inhibitory cytokine-1 (MIC-1) are linked to docetaxel resistance. Mahon et al. (46) demonstrated that expression levels of several inflammatory cytokines were associated with docetaxel resistance in vitro. Other studies underline that increased CCL2 expression is associated with tumour progression, invasiveness, and poor prognosis. AR activation has been shown to enhance macrophage recruitment via CCL2 up-regulation (47).

\section{AR Receptor Variants in Taxane Sensitivity}

Several works have suggested that the microtubule network in prostate cells is critical for AR signaling and nuclear translocation, where AR exerts its transcriptional activity. Docetaxel effectively targets the AR signaling axis in CRPC by blocking its nuclear translocation through microtubule stabilization. AR splice variants were found to be implicated in sensitivity to taxanes.

Thadani-Mulero et al. $(12,13)$ studied the two most clinically prevalent receptor splice variants, AR-V567 and AR-V7, presenting different taxane sensitivity, both in vitro and in vivo. It was reported that taxane treatment did not affect nuclear accumulation and transcriptional activity of AR-V7, whereas inhibited splice variant AR-V567. Molecular analysis demonstrated the lack of the hinge region in AR-V7, which might explain the differential interaction of the splice variants with the microtubule system. Zhang et al. (14) found that the expression of major variant AR-V7 was up-regulated in taxane-resistant cell lines. However, Onstenk and colleagues (48) investigated the response to cabazitaxel related to the AR-V7 status of CTCs from mCRPC patients.
According to their phase-II study, sensitivity to cabazitaxel was independent of AR-V7 variants. Thus, cabazitaxel might be a valid treatment option for AR-V7-positive patients.

Antonarakis et al. (49) studied clinical implication of AR-V7 variant status on taxane treatment outcome. In taxane-treated patients, no statistically significant differences were observed in PSA response, PSA progression-free survival (PFS), and median PFS according to AR-V7 status (AR-V7-positive vs. AR-V7-negative patients). However, in AR-V7-positive patients, when considering clinical outcomes, taxanes appeared superior to AR-directed therapy. This study revealed a higher PSA response, a longer PSA PFS and a better median PFS in MCRPC patients treated with taxane $v s$. AR-directed therapy.

Currently, ongoing prospective clinical trials aim to investigate AR-V7 status in taxane-treated mCRPC (50). In conclusion, more evidence is required to define the role of $\mathrm{AR}-\mathrm{V} 7$ variant as a treatment-specific biomarker in CRPC.

\section{AR Mutation and Expression of Constitutively Active AR-variants}

About $10-30 \%$ of CRPC patients reported an AR mutation (51). Known AR mutations include gene amplification, which leads to the overexpression of the receptor, point mutations, and constitutively active AR splice variants. AR point mutations in the regions coding for the ligand-binding domain (LBD) are implicated in drug resistance (52). These mutations may alter ligand binding and result in gain of AR function (53). AR point mutations are becoming more involved in the acquired resistance to abiraterone and nextgeneration AR antagonists (enzalutamide and apalutamide) (54). The AR mutation Phe876Leu results in the switch of ligand-binding specificity from agonist to antagonist and it has been associated with resistance to second-generation antiandrogens enzalutamide and ARN-509 (55).

Moreover, in abiraterone/prednisone-treated patients, the AR T878A and AR L702H mutations were also studied, which may facilitate the AR activation by progesterone or by glucocorticoids, respectively (56). It has been shown that patients harboring these activating AR mutations have worse survival compared to patients that harbor neither mutated nor amplified AR. The genome rearrangement and alternative splicing of splicing factors, such as hnRNPAs (57), generate truncated versions of the wild type gene AR, called "AR splice variants", which lack the LBD but are often ligandindependent and constitutively active (58). The expression of AR splice variants has been implicated mostly in abiraterone and enzalutamide resistance. Amongst the 22 AR splice variants known, AR-V7 is the most expressed and studied. Antonarakis et al. published a prospective study on a cohort of 62 patients treated with enzalutamide or abiraterone, in which AR-V7 status was determined by a circulating tumor 
cell (CTC)-based real-time polymerase chain reaction (PCR). They found an association between AR-V7 expression and clinical outcome. More specifically, both treatments with enzalutamide or abiraterone in patients with AR-V7 positive expression had significantly lower PSA response, shorter PFS and OS compared to AR-V7 negative patients (59). Although these results should be confirmed in larger prospective studies, they strongly suggest that patients with AR-V7 positive CTCs may have primary resistance to abiraterone and enzalutamide. As mentioned above, no changes in PSA response and PFS were observed in patients with high level of AR-V7, treated with docetaxel or cabazitaxel, suggesting that AR-V7-positive patients may be better candidates for taxanes as primary treatment $(49,50)$. Also, preliminary data on liquid biopsy for CTCs-based AR-V7 analysis showed that some patients may develop this aberration upon disease progression, as well as other AR-V7-positive patients may become AR-V7-negative after treatment with taxane-based chemotherapy. However, these data need to be confirmed.

\section{Non-genomic AR Resistance}

Ligand-independent activation of AR may be heightened by the activated pathways of non-genomic AR signaling. Although AR action mainly occurs in the cell nucleus, where it regulates the expression of target genes (canonical signaling of AR), the initial androgen binding to AR LBD in the cytoplasm may already initiate signal transduction pathways capable of influencing cell proliferation and migration (nongenomic signaling of AR) (60). This pathway is generally androgen-dependent, but it can be also triggered by growth factors and their receptors in the absence of androgens (61). Bicalutamide and flutamide are not effective in blocking nongenomic activation of AR. The second-generation antiandrogens, such as enzalutamide, apalutamide (ARN-509), and darolutamide (ODM-201), show higher affinity for the AR LBD and could minimize nuclear translocation of full-length AR, resulting in the AR cytosol accumulation $(62,63)$. Cytosolic AR could interact with Src3 and PI3K proteins activating their intracellular signaling pathways and enhancing cell proliferation and survival. In presence of low androgen levels, as occurred during an antiandrogen therapy, the proline-rich sequence between residues 371 and 381 in the $\mathrm{N}$ terminal domain (NTD) of AR interacts with Src homology domain 3 (SH3), activating prominent intracellular signaling pathways to enhance cell proliferation and survival. Indeed, the release of epidermal growth factor (EGF) or IL-6 as well as MAPKs, phosphoinositide 3-kinase (PI3K)/Akt and protein kinase A pathways were implicated in the stimulation of ligand-independent AR activity by a non-genomic mechanism.

Meanwhile, the expression of constitutively active AR splice variants, such as AR-V567es and V7, localized in the nuclei, do not mediate non-genomic signaling. Other splice variants have been discovered to have non-genomic actions, mainly AR8 and AR23. AR8 is endogenously expressed in several CRPC cell lines (C4-2B, 22Rv1, and CWR-R1) and is responsible of androgen-independent growth. AR23 is a cytosolic AR variant able to potentiate transcription, mediated by full-length AR and influence transactivation of NF-kB in reporter gene assays (64).

\section{New Treatment Strategies Focus on Non-genomic Resistance}

A new class of drugs that inhibit the AR NTD interaction with Src kinase may be considered to block non-genomic signals from full-length AR, or possibly membrane-associated or cytosolic AR splice variants, in order to prevent tumor growth. In vitro studies have shown that it is possible to block the growth of prostate tumor cell lines by blocking the AR/Src3 interaction through the use of proteins that mimic or eliminate the AR polypromine sequence (65). Non-genomic effects of AR might be also prevented by destroying AR protein or by non-AR-targeting compounds, such as galeterone (TOK-001) and niclosamide, discussed in the paragraph below.

\section{New Treatment Strategies Focus on Suppressing AR Activity}

Several ongoing trials aim at examining the efficacy of novel drugs (ARN-509 and ODM-201) targeting AR splice variants, in order to overcome mechanisms of resistance to the novel AR targeting molecules (abiraterone acetate and MDV-3100) (66-67). ARN-509, a next-generation AR antagonist, showed clinical benefit in mCRPC patients with or without prior abiraterone acetate/prednisone treatment, with a good toxicity profile (67). Darolutamide (ODM-201), is a full AR antagonist with very high-affinity to LBD and able to inhibit AR nuclear translocation. ODM-201 may also antagonize the F876L mutated AR, which was detected and probably involved in some cases of acquired resistance to ARN-509 and ENZ. In phase I/II clinical trial ODM-201 showed a promising anticancer activity in both chemotherapy-naïve and pre-treated mCRPC patients, but significantly lower in patients previously treated with CYP17 inhibitors (66). Thus, it was hypothesized that ODM-201 could be used in case of ENZ, ARN-509, bicalutamide, and flutamide resistance. Therefore, a phase III trial to assess the efficacy of ODM-201 plus standard ADT plus docetaxel (6 cycles after randomization) in men with metastatic hormonesensitive prostate cancer is ongoing (NCT02799602).

A desirable feature of AR NTD antagonists is their ability to inhibit full length-AR and AR splice variants, regardless of AR LBD. Two families of compounds are involved in binding the AR NTD and inhibiting transactivation: sintokamide A and EPI compounds (68-69). In particular, 
both these agents have shown promising results in overcoming the resistance to enzalutamide in CRPC xenografts, in mice. EPI is a drug that covalently binds the NTD of both AR and AR variants, inhibiting their transcriptional activity. In vivo administration of EPI in PCa xenograft models was observed to reduce tumor growth. EPI-506 (ralaniten acetate) is the first AR NTD antagonist to be tested in clinical trials for mCRPC (NCT02606123). Recently, the safety results of the open-label, single-arm, phase 1/2 study testing EPI-506 mCRPC patients progressed after $\geq 1$ line of hormonal therapy or chemotherapy and progressed on enzalutamide and/or abiraterone have been presented during 2017 ASCO meeting. Data on the eighteen patients enrolled showed that EPI-506 is well-tolerated (70).

Identification of agents able to overcome mechanism of resistance by inhibiting the AR outside of LBD may be an effective strategy to reintroduce drug sensitivity and decrease CRPC tumor progression (71).

Niclosamide, recently approved by the Food and Drug Administration (FDA), is an anti-helminthic drug with a known AR-V7 inhibitory activity. Niclosamide induced both degradation of AR-V7 protein and genes transcriptional activity (72). Moreover, niclosamide improves enzalutamide sensitivity by modulating Stat3 activity. In particular, this drug is able to inhibit Stat3 phosphorylation, to reduce target gene expression, and to abrogate recruitment of AR to the PSA promoter (73). Another study by Nadiminty et al. showed that CRPC cells resistant to enzalutamide were resensitized by down-regulating the splicing factor hnRNPA1, which was implicated in the AR-V7 expression (57).

Galeterone (TOK-001) is a novel agent under investigation that could potentially target full length and ARV7 splice variants (74). It acts both as an inhibitor of the enzyme CYP17A1 and as a direct AR antagonist, that has been shown to prevent $\mathrm{AR}$ binding to chromatin and enhance AR mutant degradation in PCa cell lines (75).

ASC-J9, a molecule studied in xenograft tumor models, showed the ability to decrease prostate tumor growth by degrading both full length and AR-V3 splice variants (76).

Finally, niphatenones are another class of drugs that target the NTD; however, alkylation reaction test using glutathione revealed that niphatenone $\mathrm{B}$ enantiomers are random alkylators forming adducts with glutathione. Therefore, niphatenones as non-selective alkylators due to potential haptenization and toxicity were not recommended as promising candidates for PCa therapy (77).

\section{The Future of Targeted Therapies and Precision Cancer Care}

"Precision medicine" is a novel approach for personalized disease management based on specific genetic and environmental biomarkers for each patient. Thus, biomarkers providing patient- or tumor-specific information are critical in precision medicine applied to oncology (78).

In $\mathrm{PCa}$, there are prognostic biomarkers which have been variously associated with different end-points including: PSA level, lactic dehydrogenase (LDH), alkaline phosphatase and hemoglobin. Many other potential biomarkers also exist, such as: CTCs count $(79,80)$, DNA aberrations, and RNA transcriptional profiling (81). Biomarkers are ideally able to predict sensitivity or resistance to a particular therapy. As already mentioned, much attention has been given to AR-V7 in CTC RNA assays, as a predictive biomarker of resistance to abiraterone and enzalutamide. AR gene, located on Xq12 consists of eight exons and many other DNA regions with regulatory activity. AR gene splicing may contribute to the development of truncated AR variants which are more frequent in CRPC than in hormone-naïve PCa patients. Specifically, the AR-V7 is devoid of LBD for androgens. The presence of AR-V7 protein in CTCs has been associated with resistance to AR-directed therapy, but not to taxanes $(49,59)$.

Furthermore, mCRPCs show an extensive mutational landscape, which indicates the possibility of targeted therapies and precision medicine. The use of genomic profiling of single tumors is rapidly changing treatment strategies across different cancer types, including mCRPC.

Recent reports based on the use of integrative wholeexome sequencing (WES) and whole transcriptome sequencing in metastatic site (bone or soft tissue) biopsies from 150 mCRPC patients have shown that about $90 \%$ of mCRPC harbor a potentially actionable molecular alteration including: $63 \%$ aberrations in AR (enriched in $\mathrm{mCRPC}$ compared to primary $\mathrm{PCa}$ ), $65 \%$ aberrations in other cancerrelated genes (e.g. ETS, TP53, PTEN), 23\% aberrations of DNA repair pathway (BRCA1, BRCA2, ATM), and $8 \%$ pathogenic germ-line alterations and epigenomic alterations (DNA methylation, HDAC) (82).

Manish Kohli et al. have more recently shown results of their whole-exome/RNA-sequencing analysis in metastatic biopsies from 92 CRPC patients treated with abiraterone acetate plus prednisone. The gene analysis of non-responder patients (progression at 12-weeks of therapy) revealed frequent mutations in Wnt/beta-catenin pathway genes and frequent deletion of negative regulators of Wnt pathway (DKK4, SFRP2, and LRP6). The authors also revealed a different expression level of $\mathrm{Wnt} /$ beta catenin pathway inhibitors and cell cycle proliferation genes in non-responders (83).

Furthermore, recent evidence from a study on molecular signature in PCa has suggested the possibility to identify the "aggressive variant of PCa" (AVPC), a morphologically heterogeneous PCa which clinically mimics the behaviour of small cell PCa. Authors showed that AVPC can be diagnosed based on a distinct molecular signature (MS), defined as combined tumor suppression defects of $\geq 2$ alterations of tp53, RB1 and/or PTEN by immunohistochemistry (IHC) or 
Table II. Principal clinical trials in advanced castration-resistant prostate cancer.

\begin{tabular}{|c|c|c|c|c|}
\hline & Gene & Potential therapeutic & Current clinical trials/therapies & Phase \\
\hline \multirow[t]{9}{*}{ Androgen receptor } & Androgen receptor & Mifepristone (RU-486) & NCT00140478 & Phase 2 \\
\hline & & Mifepristone/enzalutamide & NCT02012296 & Phases 1, 2 \\
\hline & & Galeterone & NCT02438007 & Phase 3 \\
\hline & & GTx-758 & NCT01615120 & Phase 2 \\
\hline & & VT-464 & NCT02445976 & Phase 2 \\
\hline & & Trilostane & NCT00181597 & Phase 2 \\
\hline & & AZD3514 & NCT01162395 & Phase 1 \\
\hline & & Orteronel (TAK-700) & $\begin{array}{c}\text { NCT00569153, NCT01809691, } \\
\text { NCT01809691 }\end{array}$ & Phases 1, 2, 3 \\
\hline & & Triamcinalone & NCT00186108 & Phase 1 \\
\hline \multirow[t]{4}{*}{ Immunotherapy } & & Ipilimimab + ADT & NCT01377389 & Phase 2 \\
\hline & & AR DNA Vaccine & NCT02411786 & Phase 1 \\
\hline & & Ipilimimab & NCT00170157 & Phase 2 \\
\hline & & BNIT-PR-001 & & Phase 1 \\
\hline \multirow[t]{4}{*}{ PIK3CA } & PIK3CA & Buparlisib (BKM120) & NCT02487823 & Phase 1 \\
\hline & PIK3CB & AZD8186 & NCT01884285 & Phase 1 \\
\hline & PIK3CB & GSK2636771/enzalutamide & NCT02215096 & Phase 1 \\
\hline & PIK3CB & GDC-0068/abiraterone & NCT01485861 & Phase 2 \\
\hline \multirow[t]{3}{*}{ Cell Cycle } & BCL-2 & Navitoclax/abiraterone & NCT01828476 & Phase 2 \\
\hline & CDK4/6 & Ribociclib & NCT02555189 & Phases 1,2 \\
\hline & $\mathrm{CDK} 4 / 6$ & PD 0332991 & NCT02059213 & Phase 2 \\
\hline \multirow[t]{4}{*}{ DNA damage } & PARP & Niraparib/enzalutamide & NCT02500901, NCT00749502 & Phase 1 \\
\hline & & Olaparib/enzalutamide & NCT01972217 & Phase 2 \\
\hline & & BMN 673 & NCT01286987 & Phase 1 \\
\hline & & Veliparib & NCT00892736 & Phase 1 \\
\hline \multirow[t]{2}{*}{ WNT } & WNT & Foxy-5 & NCT02020291 & Phase 1 \\
\hline & & OMP-54F28 & NCT01608867 & Phase 1 \\
\hline
\end{tabular}

ADT, Androgen deprivation therapy; AR, androgen receptor; PIK3CA, phosphatidylinositol-4,5-bisphosphate 3-kinase catalytic subunit alpha; BCL2, B-cell lymphoma 2; CDK4/6, cyclin-dependent kinase 4 and 6; PARP, poly (ADP-ribose) polymerase.

genomic analysis (84). They also studied AVPC-MS (by IHC) in mCRPC patients treated with taxane alone or with platinum. In $160 \mathrm{mCRPC}$ patients enrolled in the phase 2 clinical trial comparing cabazitaxel $(\mathrm{CAB})$ to $\mathrm{CAB}$ plus carboplatin (CARB), it was found that AVPC-MS (by IHC) patients had longer mPFS when they received CARB in addition to CAB. Thus, AVPC-MS was suggested as a potential predictor for platinum benefit. Results from genomic profiling of DNA samples are pending (85).

In conclusion of the aforementioned, the $\mathrm{AR}$ and its signaling pathway remain the principal drivers of development and progression of $\mathrm{PCa}$, even in the advanced stages of disease (like CRPC). For this reason, they remain the main targets of the principal therapeutic approaches for $\mathrm{PCa}$. A key question for the choice among the different available drug options is how to identify patients that will most benefit from their use.

Validated biomarkers in precision cancer care may be used for the selection of targeted therapies (when the biomarker is the target itself) or for the identification of patients more responsive to the standard therapies. Many ongoing clinical trials (Table II) explore the potential precision medicine applications in advanced CRPC and may respond to these questions.

\section{References}

1 Khuntia D, Reddy CA, Mahadevan A, Klein EA and Kupelian PA: Recurrence-free survival rates after external-beam radiotherapy for patients with clinical T1-T3 prostate carcinoma in the prostate-specific antigen era: what should we expect? Cancer 100: 1283-1292, 2004.

2 Han M, Partin AW, Zahurak M, Piantadosi S, Epstein JI and Walsh PC: Biochemical (prostate specific antigen) recurrence probability following radical prostatectomy for clinically localized prostate cancer. J Urol 169: 517-523, 2003.

3 Simmons MN, Stephenson AJ and Klein EA: Natural history of biochemical recurrence after radical prostatectomy: risk assessment for secondary therapy. EurUrol 51: 1175-1184, 2007.

4 Scher HI, Halabi S, Tannock I Morris M, Sternberg CN, Carducci MA, Eisenberger MA, Higano C, Bubley GJ, Dreicer R, Petrylak D, Kantoff P, Basch E, Kelly WK, Figg WD, Small EJ, Beer TM, Wilding G, Martin A and Hussain M: Design and end points of clinical trials for patients with progressive prostate 
cancer and castrate levels of testosterone: recommendations of the Prostate Cancer Clinical Trials Working Group. J Clin Oncol 26(7): 1148-1159, 2008.

5 Petrylak DP, Tangen CM, Hussain MH, Lara PN Jr, Jones JA, Taplin ME, Burch PA, D, Moinpour C, Kohli M, Benson MC, Small EJ, Raghavan D and Crawford ED: Docetaxel and estramustine compared with mitoxantrone and prednisone in advanced refractory prostate cancer. New Engl J Med 351: 1513-1520, 2004.

6 Tannock IF, deWit R, Berry WR, Horti J, Pluzanska A, Chi KN, Oudard S, Théodore C, James ND, Turesson I, Rosenthal MA, Eisenberger MA and TAX 327 Investigators: Docetaxel plus prednisone or mitoxantrone plus prednisone for advanced prostate cancer. New Engl J Med 351: 1502-1512, 2004.

7 De Bono JS, Oudard S, Ozguroglu M, Hansen S, Machiels JP, Kocak I, Gravis G, Bodrogi I, Mackenzie MJ, Shen L, Roessner M, Gupta S, Sartor AO and TROPIC Investigators: Prednisone plus cabazitaxel or mitoxantrone for metastatic castrationresistant prostate cancer progressing after docetaxel treatment: a randomized open-label trial. Lancet 376(9747): 1147-1154, 2010.

8 Parker C, Nilsson S, Heinrich D, Helle SI, O'Sullivan JM, Fosså SD, Chodacki A, Wiechno P, Logue J, Seke M, Widmark A, Johannessen DC, Hoskin P, Bottomley D, James ND, Solberg A, Syndikus I, Kliment J, Wedel S, Boehmer S, Dall'Oglio M, Franzén L, Coleman R, Vogelzang NJ, O'Bryan-Tear CG, Staudacher K, Garcia-Vargas J, Shan M, Bruland ØS, Sartor O and ALSYMPCA Investigators.: Alpha emitter radium-223 and survival in metastatic prostate cancer. N Engl J Med 369: 213-223, 2013.

9 Armstrong $\mathrm{CM}$ and Gao AC: Drug resistance in castration resistant prostate cancer: resistance mechanisms and emerging treatment strategies. Am J Clin Exp Urol 3(2): 64-76, 2015.

10 Vrignaud P, Semiond D, Benning V, Beys E, Bouchard H and Gupta S: Preclinical profile of cabazitaxel. Drug Des Devel Ther 8: 1851-1867, 2014.

11 Ploussard G, Terry S, Maillé P, Allory Y, Sirab N, Kheuang L, Soyeux P, Nicolaiew N, Coppolani E, Paule B, Salomon L, Culine S, Buttyan R, Vacherot F and de la Taille A: Class III $\beta$ tubulin expression predicts prostate tumor aggressiveness and patient response to docetaxel-based chemotherapy. Cancer Res 70: 9253-9264, 2010.

12 Thadani-Mulero M, Nanus DM and Giannakakou P: Androgen receptor on the move: boarding the microtubule expressway to the nucleus. Cancer Res 72(18): 4611-4615, 2012.

13 Thadani-Mulero M, Portella L, Sun S, Sung M, Matov A, Vessella RL, Corey E, Nanus DM, Plymate SR and Giannakakou P: Androgen receptor splice variants determine taxane sensitivity in prostate cancer. Cancer 74(8): 2270-2282, 2014.

14 Zhang G, Liu X, Li J, Ledet E, Alvarez X, Qi Y, Fu X, Sartor $\mathrm{O}$, Dong $\mathrm{Y}$ and Zhang H: Androgen receptor splice variants circumvent AR blockade by microtubule-targeting agents. Oncotarget 6(27): 23358-23371, 2015.

15 Terry S, Ploussard G, Allory Y, Nicolaiew N, Boissière-Michot F, Maillé P, Kheuang L, Coppolani E, Ali A, Bibeau F, Culine S, Buttyan R, de la Taille A and Vacherot F: Increased expression of class III $\beta$-tubulin in castration-resistant human prostate cancer. Br J Cancer 101: 951-956, 2009.

16 Ranganathan S, McCauley RA, Dexter DW and Hudes GR: Modulation of endogenous $\beta$-tubulin isotype expression as a result of human $\beta(\mathrm{III}) \mathrm{CDNA}$ transfection into prostate carcinoma cells. Br J Cancer 85: 735-740, 2001.
17 Hari M, Loganzo F, Annable T, Tan X, Musto S, Morilla DB, Nettles JH, Snyder JP and Greenberger LM: Paclitaxel-resistant cells have a mutation in the paclitaxel-binding region of $\beta$ tubulin (Asp26Glu) and less stable microtubules. Mol Cancer Ther 5: 270-278, 2006.

18 Hara T, Ushio K, Nishiwaki M, Kouno J, Araki H, Hikichi Y, Hattori M, Imai Y and Yamaoka M: A mutation in $\beta$-tubulin and a sustained dependence on androgen receptor signalling in a newly established docetaxel-resistant prostate cancer cell line. Cell Bio Int 34: 177-184, 2010.

19 Souchek JJ, Davis AL, Hill TK, Holmes MB, Qi B, Singh PK, Kridel SJ and Mohs AM: Combination treatment with orlistatcontaining nanoparticles and taxanes is synergistic and enhances microtubule stability in taxane-resistant prostate cancer cells. Mol Cancer Ther 16(9): 1819-1830, 2017.

20 Wang Y, Yu Y, Li GB, Li SA, Wu C, Gigant B, Qin W, Chen H, Wu Y, Chen Q and Yang J: Mechanism of microtubule stabilization by taccalonolide AJ. Nat Commun 8: 15787, 2017.

21 Sircar K, Huang H, Hu L, Liu Y, Dhillon J, Cogdell D, Aprikian A, Efstathiou E, Navone N, Troncoso P and Zhang W: Mitosis phase enrichment with identification of mitotic centromereassociated kinesin as a therapeutic target in castration-resistant prostate cancer. PLoS ONE 7(2): e31259, 2012.

22 Wissing MD, De Morrée ES, DezentjéVO, Buijs JT, De Krijger RR, Smit VT, Van Weerden WM, Gelderblom $H$ and van der Pluijm G: Nuclear Eg5 (kinesin spindle protein) expression predicts docetaxel response and prostate cancer aggressiveness. Oncotarget 5(17): 7357-7367, 2014.

23 Sharom FJ: ABC multidrug transporters: structure, function and role in chemoresistance. Pharmacogenomics 9(1): 105-127, 2008.

24 Kawai K, Sakurai M, Sakai T, Misaki M, Kusano I, Shiraishi T and Yatani R: Demonstration of MDR1 P-glycoprotein isoform expression in benign and malignant human prostate cells by isoform-specific monoclonal antibodies. Cancer Lett 150(2): 147-153, 2000.

25 van Brussel JP, van Steenbrugge GJ, Romijn JC, Schröder FH and Mickisch GH: Chemosensitivity of prostate cancer cell lines and expression of multidrug resistance-related proteins. Eur $\mathbf{J}$ Cancer 35(4): 664-671, 1999.

26 Zhu Y, Liu C, Nadiminty N, Tummala R, Evans CP and Gao AC: Inhibition of $\mathrm{ABCB} 1$ expression overcomes acquired docetaxel resistance in prostate cancer. Mol Cancer Ther 12(9): 1829-1836, 2013.

27 Zhu Y, Liu C, Armstrong C, Lou W, Sandher A and Gao AC: Antiandrogens inhibit ABCB 1 efflux and ATPase activity and reverse docetaxel resistance in advanced prostate cancer. Clin Cancer Res 21(18): 4133-4142, 2015.

28 Oprea-Lager DE, Bijnsdorp IV, VAN Moorselaar RJ, van den Eertwegh AJ, Hoekstra OS and Geldof AA: ABCC4 decreases docetaxel and not cabazitaxel efficacy in prostate cancer cells in vitro. Anticancer Res 33(2): 387-391, 2013.

29 Cai C, Omwancha J, Hsieh CL and Shemshedini L: Androgen induces expression of the multidrug resistance protein gene MRP4 in prostate cancer cells. Prostate Cancer Prostatic Dis 10: 39-45, 2007.

30 Tomlins SA, Rhodes DR, Perner S Dhanasekaran SM, Mehra R, Sun XW, Varambally S, Cao X, Tchinda J, Kuefer R, Lee C, Montie JE, Shah RB, Pienta KJ, Rubin MA and Chinnaiyan AM: Recurrent fusion of TMPRSS2 and ETS transcription factor genes in prostate cancer. Science 310: 644-648, 2005. 
31 Brenner JC, Ateeq B, Li Y, Yocum AK, Cao Q, Asangani IA Patel S, Wang X, Liang H, Yu J, Palanisamy N, Siddiqui J, Yan W, Cao X, Mehra R, Sabolch A, Basrur V, Lonigro RJ, Yang J, Tomlins SA, Maher CA, Elenitoba-Johnson KS, Hussain M, Navone NM, Pienta KJ, Varambally S, Feng FY and Chinnaiyan AM: Mechanistic rationale for inhibition of poly(ADP-ribose) polymerase in ETS gene fusion-positive prostate cancer. Cancer Cell 19(5): 664-678, 2011.

32 Galletti G, Matov A, Beltran H, Fontugne J, Miguel Mosquera J, Cheung C, MacDonald TY, Sung M1, O'Toole S, Kench JG, Suk Chae S, Kimovski D, Tagawa ST, Nanus DM, Rubin MA, Horvath LG, Giannakakou P and Rickman DS: ERG induces taxane resistance in castration-resistant prostate cancer. Nat Commun 5: 5548, 2014.

33 Cai C, Wang H, XuY, Chen S and Balk SP: Reactivation of androgen receptor-regulated TMPRSS2: ERG gene expression in castration-resistant prostate cancer. Cancer Res 69: 60276032, 2009.

34 Roudier MP, Winters BR, Coleman I, Chen S and Balk SP: Characterizing the molecular features of ERG-positive tumors in primary and castration resistant prostate cancer. Prostate 76: 810-822, 2016.

35 Rahim S and Uren A: Emergence of ETS transcription factors as diagnostic tools and therapeutic targets in prostate cancer. Am J Transl Res 5: 254-268, 2013.

36 Patterson SG, Wei S, Chen X, Sallman DA, Gilvary DL, Zhong B, Pow-Sang J, Yeatman T and Djeu JY: Novel role of Stat1 in the development of docetaxel resistance in prostate tumor cells. Oncogene 25(45): 6113-6122, 2006.

37 West KA, Castillo SS and Dennis PA: Activation of the PI3K/Akt pathway and chemotherapeutic resistance. Drug Resist Updat 5(6): 234-248, 2002.

38 Yoshino T, Shiina H, Urakami S, Kikuno N, Yoneda T, Shigeno $\mathrm{K}$, Igawa $\mathrm{M}$ : Bcl-2 expression as a predictive marker of hormone-refractory prostate cancer treated with taxane-based chemotherapy. Clin Cancer Res 12: 6116-6124, 2006.

39 Plymate SR, Bhatt RS and Balk SP: Taxane resistance in prostate cancer mediated by AR-independent GATA2 regulation of IGF2. Cancer Cell 27(2): 158-159, 2015.

40 Vidal SJ, Rodriguez-Bravo V, Quinn SA, Rodriguez-Barrueco R, Lujambio A, Williams E4, Sun X, de la Iglesia-Vicente J, Lee A, Readhead B, Chen X, Galsky M, Esteve B, Petrylak DP, Dudley JT, Rabadan R, Silva JM, Hoshida Y, Lowe SW, CordonCardo C and Domingo-Domenech J: A targetable GATA2-IGF2 axis confers aggressiveness in lethal prostate cancer. Cancer Cell 27: 223-239, 2015.

41 Domingo-Domenech J, Vidal SJ, Rodriguez-Bravo V, CastilloMartin M, Quinn SA, Rodriguez-Barrueco R, Bonal DM, Charytonowicz E, Gladoun N, de la Iglesia-Vicente J, Petrylak DP, Benson MC, Silva JM and Cordon-Cardo C.: Suppression of acquired docetaxel resistance in prostate cancer through depletion of notch- and hedgehog-dependent tumor-initiating cells. Cancer Cell 22: 373, 2012.

42 Liu C, Zhu Y, Lou W, Nadiminty N, Chen X, Zhou Q, Shi XB, deVere White RW and Gao AC: Functional p53 determines docetaxel sensitivity in prostate cancer cells. Prostate 73: 418427, 2013.

43 Puhr M, Hoefer J, Schäfer G Erb HH, Oh SJ, Klocker H, Heidegger I, Neuwirt H and Culig Z: Epithelial-to-mesenchymal transition leads to docetaxel resistance in prostate cancer and is mediated by reduced expression of miR-200c and miR-205. Am J Pathol 181(6): 2188-2201, 2012.

44 Marín-Aguilera M, Codony-Servat J, Reig Ò, Lozano JJ, Fernández PL, Pereira MV, Jiménez N, Donovan M, Puig P, Mengual L, Bermudo R, Font A, Gallardo E, Ribal MJ, Alcaraz A, Gascón P and Mellado B: Epithelial-to-mesenchymal transition mediates docetaxel resistance and high risk of relapse in prostate cancer. Mol Cancer Ther 13(5): 1270-1284, 2014.

45 Qian DZ, Rademacher BL, Pittsenbarger J, Huang CY, Myrthue A, Higano CS, Garzotto M, Nelson PS and Beer TM: CCL2 is induced by chemotherapy and protects prostate cancer cells from docetaxel-induced cytotoxicity. Prostate 70(4): 433-442, 2010.

46 Mahon KL, Lin HM, Castillo L, Lee BY, Lee-Ng M, Chatfield MD, Chiam K, Breit SN, Brown DA, Molloy MP, Marx GM, Pavlakis N, Boyer MJ, Stockler MR, Daly RJ, Henshall SM and Horvath LG: Cytokine profiling of docetaxel-resistant castrationresistant prostate cancer. Br J Cancer 112(8): 1340-1348, 2015.

47 Izumi K, Fang LY, Mizokami A, Namiki M, Li L, Lin WJ and Chang C: Targeting the androgen receptor with siRNA promotes prostate cancer metastasis through enhanced macrophage recruitment via CCL2/CCR2-induced STAT3 activation. EMBOMol Med 5(9): 1383-1401, 2013.

48 Onstenk W, Sieuwerts AM, Kraan J Van M, Nieuweboer AJ, Mathijssen RH, Hamberg P, Meulenbeld HJ, De Laere B, Dirix LY, van Soest RJ, Lolkema MP, Martens JW, van Weerden WM, Jenster GW, Foekens JA, de Wit R and Sleijfer S: Efficacy of cabazitaxel in castration-resistant prostate cancer is independent of the presence of AR-V7 in circulating tumor cells. Eur Urol 68(6): 939-945, 2015.

49 Antonarakis ES, Lu C, Luber B Wang H, Chen Y, Nakazawa M, Nadal R, Paller CJ, Denmeade SR, Carducci MA, Eisenberger MA and Luo J: Androgen receptor splice variant 7 and efficacy of taxane chemotherapy in patients with metastatic castrationresistant prostate cancer. JAMA Oncol 1(5): 582-591, 2015.

50 Antonorakis ES, Tagawa ST, Galletti G, Worroll D, Ballman K, Vanhuyse M, Sonpavde G, North S, Albany C, Tsao CK, Stewart J, Zaher A, Szatrowski T, Zhou W, Gjyrezi A, Tasaki S, Portella L, Bai Y, Lannin TB, Suri S, Gruber CN, Pratt ED, Kirby BJ, Eisenberger MA, Nanus DM, Saad F and Giannakakou P; TAXYNERGY Investigators: Randomized, noncomparative, phase ii trial of early switch from docetaxel to cabazitaxel or vice versa, with integrated biomarker analysis, in men with chemotherapy-naïve, metastatic, castration-resistant prostate cancer. J Clin Oncol 35(28): 3181-3188, 2017.

51 Waltering KK, Urbanucci A and Visakorpi T: Androgen receptor (AR) aberrations in castration-resistant prostate cancer. Mol Cell Endocrinol 360: 38-43, 2012.

52 Armstrong $\mathrm{CM}$ and Gao AC: Drug resistance in castration resistant prostate cancer: resistance mechanisms and emerging treatment strategies. Am J ClinExpUrol 3(2): 64-76, 2015.

53 Eisermann K, Wang D, Jing Y, Pascal LE and Wang Z: Androgen receptor gene mutation, rearrangement, polymorphism. TranslAndrolUrol 2: 137-147, 2013.

54 Smith MR, Antonarakis ES, Ryan CJ, Berry WR, Shore ND, Liu G, Alumkal JJ, Higano CS, Chow Maneval E, Bandekar R, de Boer CJ, Yu MK and Rathkopf DE: Phase 2 study of the safety and antitumor activity of Apalutamide (ARN-509), a potent androgen receptor antagonist, in the high-risk nonmetastatic castrationresistant prostate cancer cohort. Eur Urol 70(6): 963-970, 2016. 
55 Joseph JD, Lu N, Qian J, Sensintaffar J, Shao G, Brigham D, Moon M, Maneval EC, Chen I, Darimont B, Hager JH.: A clinically relevant androgen receptor mutation confers resistance to second-generation antiandrogens enzalutamide and ARN-509. Cancer Dis 3(9): 1020-1029, 2013.

56 Romanel A, GasiTandefelt D, Conteduca V, Jayaram A, Casiraghi N, Wetterskog D, Salvi S, Amadori D, Zafeiriou Z, Rescigno P, Bianchini D, Gurioli G, Casadio V, Carreira S, Goodall J, Wingate A, Ferraldeschi R, Tunariu N, Flohr P, De Giorgi U, de Bono JS, Demichelis F, Attard G: Plasma AR and abiraterone-resistant prostate cancer. SciTransl Med 7(312): 312re10, 2015.

57 Nadiminty N, Tummala R, Liu C, Lou W, Evans CP and Gao AC: NF-kB2/p52: c-Myc:hnRNPA1 pathway regulates expression of androgen receptor splice variants and enzalutamide sensitivity in prostate cancer. Mol Cancer Ther 14(8): 18841895, 2015.

58 Li Y, Alsagabi M, Fan D, Bova GS, Tew k AH and Dehm SM: Intragenic rearrangement and altered RNA splicing of the androgen receptor in a cell-based model of prostate cancer progression. Cancer Res 71: 2108-2117, 2011.

59 Antonarakis ES, Lu C, Wang H, Luber B, Nakazawa M, Roeser JC, Chen Y, Mohammad TA, Chen Y, Fedor HL, Lotan TL, Zheng Q, De Marzo AM, Isaacs JT, Isaacs WB, Nadal R, Paller CJ, Denmeade SR, Carducci MA, Eisenberger MA and Luo J: AR-V7 and resistance to enzalutamide and abiraterone in prostate cancer. N Engl J Med 371: 1028-1038, 2014.

60 Onstenk W, Sieuwerts AM, Kraan J, Van M and Nieuweboer AJ: Efficacy of cabazitaxel in castration-resistant prostate cancer is independent of the presence of AR-V7 in circulating tumor cells. Eur Urol 68(6): 939-945, 2015.

61 Migliaccio A, Castoria G and Di Domenico M: Steroid-induced androgen receptor-oestradiol receptor beta-Src complex triggers prostate cancer cell proliferation. EMBO J 19(20): 5406-5417, 2000.

62 Zarif JC, Lamb LE, Schulz VV, Nollet EA and Miranti CK: Androgen receptor non-nuclear regulation of prostate cancer cell invasion mediated by Src and matriptase. Oncotarget 6(9): 68627686, 2015.

63 Jenster G: Ligand-independent activation of the androgen receptor in prostate cancer by growth factors and cytokines. J Pathol 191(3): 227-228, 2000.

64 Jagla M, Feve M, Kessler P, Lapouge G, Erdmann E, Serra S Bergerat JP and Céraline J: A splicing variant of the androgen receptor detected in a metastatic prostate cancer exhibits exclusively cytoplasmic actions. Endocrinology 148(9): 43344343, 2007.

65 Migliaccio A, Varricchio L, De Falco A and Castoria G: Inhibition of the SH3 domain-mediated binding of Src to the androgen receptor and its effect on tumor growth. Oncogene 26(46): 6619-6629, 2007.

66 Fizazi K, Massard C, Bono P, Jones R and Kataja V: Activity and safety of ODM-201 in patients with progressive metastatic castration-resistant prostate cancer (ARADES): an open-label phase 1 dose-escalation and randomised phase 2 dose expansion trial. Lancet Oncol 15(9): 975-985, 2014.

67 Clegg NJ, Wongvipat J, Joseph JD, Tran C, Ouk S, Dilhas A, Chen Y, Grillot K, Bischoff ED, Cai L, Aparicio A, Dorow S, Arora V, Shao G, Qian J, Zhao H, Yang G, Cao C, Sensintaffar J, Wasielewska T, Herbert MR, Bonnefous C, Darimont B, Scher
HI, Smith-Jones P, Klang M, Smith ND, De Stanchina E, Wu N, Ouerfelli O, Rix PJ, Heyman RA, Jung ME, Sawyers CL and Hager JH: ARN-509: a novel antiandrogen for prostate cancer treatment. Cancer Res 72(6): 1494-1503, 2012.

68 Yang X, Guo Z, Sun F, Li W, Alfano A, Shimelis H Chen M, Brodie AM, Chen H, Xiao Z, Veenstra TD and Qiu Y: Novel membrane-associated androgen receptor splice variant potentiates proliferative and survival responses in prostate cancer cells. J BiolChem 286(41): 36152-31660, 2011.

69 Banuelos CA, Tavakoli I, Tien AH and Caley DP: Sintokamide $\mathrm{A}$ is a novel antagonist of androgen receptor that uniquely binds activation function- 1 in its amino-terminal domain. J Biol Chem 291(42): 22231-22243, 2016.

70 Kim N. Chi, Ulka N. Vaishampayan, Michael S. Gordon, David C. Smith, Erin Rudsinski, Angela De Haas-Amatsaleh, Neil Thapar, Frank Perabo and Robert B. Montgomery: Efficacy, safety, tolerability, and pharmacokinetics of EPI-506 (ralaniten acetate), a novel androgen receptor (AR) N-terminal domain (NTD) inhibitor, in men with metastatic castration-resistant prostate cancer (mCRPC) progressing after enzalutamide and/or abiraterone. J Clin Oncol 35(15 suppl): 5032-5032, 2017.

71 Antonarakis ES, Chandhasin C, Osbourne E, Luo J, Sadar MD and Perabo F: Targeting the N-terminal domain of the androgen receptor: A new approach for the treatment of advanced prostate cancer. Oncologist 21(12): 1427-1435, 2016.

72 Liu C, Lou W, Zhu Y, Nadiminty N, Schwartz CT, Evans CP and Gao AC: Niclosamide inhibits an- drogen receptor variants expression and overcomes enzalutamide resistance in castration- resistant prostate cancer. Clin Cancer Res 20: 31983210, 2014.

73 Liu C, Lou W, Armstrong C, Zhu Y, Evans CP and Gao AC: Niclosamide suppresses cell migration and invasion in enzalutamide resistant prostate cancer cells via Stat3-AR axis inhibition. Prostate 75(13): 1341-1353, 2015.

74 Bastos DA and Antonarakis ES: Galeterone for the treatment of advanced prostate cancer: the evidence to date. Drug Des DevelTher 10: 2289-2297, 2016.

$75 \mathrm{Yu} \mathrm{Z,} \mathrm{Cai} \mathrm{C,} \mathrm{Gao} \mathrm{S,} \mathrm{Simon} \mathrm{NI,} \mathrm{Shen} \mathrm{HC} \mathrm{and} \mathrm{Balk} \mathrm{SP:}$ Galeterone prevents androgen receptor binding to chromatin and enhances degradation of mutant androgen receptor. Clin Cancer Res 20(15): 4075-4085, 2014.

76 Yamashita S, Lai KP, Chuang KL, Xu D, Miyamoto H Tochigi T, Pang ST, Li L, Arai Y, Kung HJ, Yeh S and Chang C: ASCJ9 suppresses castration-resistant prostate cancer growth through degradation of full-length and splice variant androgen receptors. Neoplasia 14: 74-83, 2012.

77 Banuelos CA, Lal A, Tien AH, Shah N, Yang YC, Mawji NR, Meimetis LG, Park J, Kunzhong J, Andersen RJ and Sadar MD: Characterization of niphatenones that inhibit androgen recept- or N-terminal domain. PLoS One 9: e107991, 2014.

78 Normanno N: Precision medicine from experimental to clinical applications in oncology. Recenti Prog Med 106(12): 597-600, 2015.

79 Scher HI, Heller G, Molina A, Attard G, Danila DC Jia X, Peng W, Sandhu SK, Olmos D, Riisnaes R, McCormack R, Burzykowski T, Kheoh T, Fleisher M, Buyse M and de Bono JS: Circulating tumor cell biomarker panel as an individual-level surrogate for survival in metastatic castration-resistant prostate cancer. J ClinOncol 33: 1348-1355, 2015. 
80 de Bono JS, Scher HI, Montgomery RB, Parker C, Miller MC, Tissing H, Doyle GV, Terstappen LW, Pienta KJ and Raghavan D: Circulating tumor cells predict survival benefit from treatment in metastatic castration-resistant prostate cancer. Clin Cancer Res 14: 6302-6309, 2008.

81 Ross RVV, Galsky MD, Scher HI, Magidson J, Wassmann K, Lee GS, Katz L, Subudhi SK, Anand A, Fleisher M, Kantoff PW and Oh WK: A whole-blood RNA transcript-based prognostic model in men with castration-resistant prostate cancer: a prospective study. Lancet Oncol 13: 1105-1113, 2012.

82 Robinson D, Van Allen EM, Wu YM, Schultz N, Lonigro RJ, Mosquera JM, Montgomery B, Taplin ME, Pritchard CC, Attard G, Beltran H, Abida W, Bradley RK, Vinson J, Cao X, Vats P, Kunju LP, Hussain M, Feng FY, Tomlins SA, Cooney KA, Smith DC, Brennan C, Siddiqui J, Mehra R, Chen Y, Rathkopf DE, Morris MJ, Solomon SB, Durack JC, Reuter VE, Gopalan A, Gao J, Loda M, Lis RT, Bowden M, Balk SP, Gaviola G, Sougnez C, Gupta M, Yu EY, Mostaghel EA, Cheng HH, Mulcahy H, True LD, Plymate SR, Dvinge H, Ferraldeschi R, Flohr P, Miranda S, Zafeiriou Z, Tunariu N, Mateo J, PerezLopez R, Demichelis F, Robinson BD, Schiffman M, Nanus DM10, Tagawa ST, Sigaras A, Eng KW, Elemento O, Sboner A, Heath EI, Scher HI, Pienta KJ, Kantoff P, de Bono JS, Rubin MA, Nelson PS, Garraway LA, Sawyers CL and Chinnaiyan AM: Integrative clinical genomics of advanced prostate cancer. Cell 161(5): 1215-1228, 2015.
83 Kohli M, Wang L, Scott Dehm S, Hillman DW, Sicotte H, Gormley M, Vipul Bhargava V, Li W, Tan W, Pitot HC, Huu Ho T, Costello BA, Bryce AH, Zhenqing Y, Peter T Vedell PT, Barman P, Jimenez RE, Carlson R and Wang L: Genome-wide analysis of metastases to reveal association of pathway activation with abiraterone acetate/prednisone (AA/P) primary resistance and cell cycle proliferation pathway activation with response duration in metastatic castrate resistant prostate cancer (mCRPC). J Clin Oncol 35(15 suppl): 5053-5053, 2017.

84 Aparicio AM, Shen L, Tapia EL, Lu JF, Chen HC, Zhang J, Wu G, Wang X, Troncoso P, Corn P, Thompson TC, Broom B, Baggerly K, Maity SN and Logothetis CJ: Combined tumor suppressor defects characterize clinically defined aggressive variant prostate cancers. Clin Cancer Res 22(6): 1520-1530, 2016.

85 Aparicio AM, Xiao L, Ning Tapia EL, Hoang A, Ramesh N, Wu W, Chancoco H, Heath EI, Efstathiou E, Thompson T, Troncoso P, McIntosh Broom B, Zurita AJ, Navin N, Logothetis C and Gettys Corn P: The aggressive variant prostate carcinoma (AVPC) molecular signature (-MS) and platinum-sensitivity in castration resistant prostate cancer (CRPC). J Clin Oncol 35(15 suppl): 5013-5013, 2017.

Received August 12, 2018

Revised September 27, 2018 Accepted October 1, 2018 